\title{
KOMPENSASI DAN DUKUNGAN ORGANISASI TERHADAP KETERTARIKAN \\ PELAMAR KERJA: EFEKTIFITAS PEMBERIAN INFORMASI
}

\section{COMPENSATION AND ORGANIZATIONAL SUPPORT TOWARD APPLICANTS ATTRACTIVENESS: THE EFFECTIVENESS OF GIVING INFORMATION}

\author{
Dany Fajar Setiawan \\ Erika Setyanti Kusumaputri \\ Program Studi Psikologi, Universitas Islam Negeri Sunan Kalijaga, Yogyakarta \\ EmaiL; dany.setiawan24@gmail.com; erikakusumaputri@yahoo.co.id
}

\begin{abstract}
This research was purposed to find out the effect of company profile booklet based on compensation and company profile booklet based on organizational support toward applicants attractiveness. Furthermore, this research alsofind out which company profile booklet that has more attractiveness between company profile based on compensation or company profile booklet based on organizational support. The subjects in this research were 60 students in last term who study in Yogyakarta. The data were collected through random sampling technique. Themethod of this research was 'post test only' experiment design and using attractiveness scale. Then, this reseacrh was analized using comparison test, Mann Whitney $U$ analysis teqnique. The hypothesis was accepted if this research had significant score $p<0,05$, and the significant score of this research was 0,021, where company profile booklet based on organizational support had higher mean rank score which is $35,70 \%$, meanwhile the mean rank score of company profile based on compensation was $25,30 \%$. It also emphasized that company profile booklet based on organizational support more increase the attractiveness for applicants than company profile booklet based on compensation, and it proves that the hypothesis in this research was accepted.
\end{abstract}

Key Words: Attractiveness, Compensation, Organizational Support

\begin{abstract}
ABSTRAK
Penelitian ini bertujuan untuk mengetahui pengaruh booklet company profile berbasis kompensasi (compensation) dan dukungan organisasi (organizational support) terhadap ketertarikan (attractiveness) pelamar kerja. Penelitian ini juga melihat booklet company profile manakah yang lebih memiliki ketertarikan lebih tinggi antara booklet company profile berbasis kompensasi (compensation) atau booklet company profile berbasis dukungan organisasi (organizational support). Subjek penelitian ini adalah mahasiswa tingkat akhir yang berkuliah di Yogyakarta dengan jumlah 60 mahasiswa. Pengambilan data sampel penelitian ini menggunakan teknik random sampling. Metode penelitian adalah post test only design dan menggunakan skala ketertarikan (attractiveness). Analisis data dilakukan dengan menggunakan teknik analisis Mann Whitney $U$ Test. Hasil penelitian menunjukkan hipotesis penelitian ini diterima, dimana pada booklet company profile dukungan organisasi memiliki nilai mean rank lebih besar, yaitu 35,70\%, sedangkan booklet company profile berbasis kompensasi (compensation) hanya memiliki nilai mean rank sebesar $25,30 \%$. Hal ini sekaligus menegaskan bahwa booklet company profile berbasis dukungan organisasi lebih meningkatkan ketertarikan pelamar kerja daripada booklet company profile berbasis kompensasi.
\end{abstract}

Kata Kunci: Dukungan Organisasi, Ketertarikan, Kompensasi 
Indonesia adalah negara yang memiliki potensi ekonomi tinggi dan banyak diperhatikan dunia internasional. Hal itu terlihat dari muncul dan berkembangnya berbagai perusahaan besar dengan penawaran beragam kompensasi tinggi dan fasilitas-fasilitas perusahaan yang lengkap yang tentunya memberikan ketertarikan dan minat para pelamar kerja untuk bekerja pada perusahaan tersebut. Faktorfaktor itulah yang kemudian menjadi tujuan utama bagi pelamar kerja untuk mencari perusahaan yang mereka anggap prestisius dan tidak sedikit pelamar kerja yang menjadikannya sebagai tolok ukur perusahaan yang akan mereka cari.

Selain alasan di atas, adanya fenomena job hopping merupakan salah satu masalah sensitif bagi mayoritas perusahaan di Indonesia saat ini. Job hopping adalah istilah bagi mereka yang sering berpindah tempat kerja dalam kurun waktu yang relatif singkat. Fenomena job hopping pada dasarnya memiliki kerugian pada kedua belah pihak, yaitu bagi pelamar kerja itu sendiri dan bagi perusahaan (Careernews, 2014).

Bagi pelamar kerja yang sering berpindah kerja tentu hal ini akan banyak membuang waktu percuma saat jeda menunggu kepastian kontrak. Selain itu pertimbangan selanjutnya adalah suasana dan lingkungan kerja baru yang menuntut pelamar kerja harus terus menyesuaikan diri. Bagi perusahaan, pada dasarnya perusahaan tidak ingin kehilangan karyawan yang memiliki peran penting pada perusahaan (knowledge lost), terlebih jika knowledge lost tersebut merupakan karyawan andalan perusahaan (Kompas.com, 2016)

Munculnya fenomena-fenomena di atas terjadi dikarenakan mayoritas karyawan pada saat mencari pekerjaan lebih berorientasi pada gaji atau posisi di perusahaan, serta rendahnya kesadaran pelamar kerja terhadap hal-hal yang membuatnya bertahan pada suatu perusahaan, seperti lingkungan kerja yang kondusif dan sesuai dengan pribadi pelamar kerja (CareerNews, 2014).

Society of Human Resource Management (SHRM), menghitung bahwa setiap seorang karyawan mendapat gaji 8 dolar Amerika per jam. Jika mengundurkan diri, maka dibutuhkan biaya $\$ 3500$ untuk mengganti karyawan tersebut. Diketahui munculnya angka tersebut berdasarkan kajian yang dilakukan dan menemukan bahwa biaya karyawan yang keluar meninggalkan perusahaan dapat dibagi dalam beberapa komponen, seperti biaya perpisahan, biaya rekrutmen, biaya pengembangan karyawan, dan biaya tidak langsung (Prabowo, 2014)

Adanya dukungan organisasi di tempat kerja merupakan faktor penting yang melatarbelakangi bertahannya seorang karyawan di perusahaan. Namun, kesadaran akan faktor yang tidak nampak 
tersebut belumlah disadari secara langsung oleh karyawan sehingga seringkali karyawan mengalami ketidakcocokan dengan karakteristik organisasi, baru setelah mereka mulai bekerja di perusahaan (Roberson, Collins, \& Oreg, 2005)

Turban (2001) menjelaskan ketertarikan (attractiveness) pada perusahaan adalah hal yang sangat penting dalam hal kaitannya bagi perusahaan maupun bagi pelamar kerja. Rendahnya ketertarikan pelamar kerja terhadap suatu perusahaan tentu akan memberikan sedikit kesempatan bagi perusahaan dalam menyeleksi orang-orang yang berpotensi melakukan job hopping. Sebaliknya, sebuah perusahaan dengan ketertarikan pelamar kerja yang tinggi tentu memberikan peluang dan kesempatan yang lebih besar pula kepada perusahaan untuk mendapatkan karyawan dengan kriteria yang diharapkan.

Bagi perusahaan tentu hal ini juga akan sangat menguntungkan jika karyawan memiliki ketertarikan besar terhadap perusahaan mereka dan melamar pekerjaan di perusahaan mereka. Perusahaan akan dapat lebih leluasa meminimalisasi karyawan yang berpotensi melakukan job hopping. Begitu pun bagi pelamar kerja, ketertarikan pada perusahaan dianggap penting karena tentu setiap pelamar kerja menginginkan bekerja pada perusahaan yang diminatinya dan hal ini berkaitan dengan bertahannya karyawan di sebuah perusahaan.

Lievens, Decaesteker, Coetsier, dan Geirnet (2001) serta Highhouse, Lievens dan Sinar (2003) menyatakan ketertarikan (attractiveness) adalah pandangan yang menggabungkan gagasan atas apa yang pelamar kerja inginkan dan pelamar kerja cari dalam sebuah perusahaan, serta kemampuan perusahaan dalam memuaskan dan memberi kesejahteraan pada karyawannya. Setiap individu memiliki perbedaan ketertarikan pada organisasi terkait pada kebutuhan, persepsi ketertarikan, jenis perusahaan dan karakteristik perusahaan. Terdapat tiga komponen ketertarikan di antaranya adalah persepsi ketertarikan (attractiveness perception), intention (keinginan), dan prestise (prestige).

Salah satu faktor penyebab yang memengaruhi ketertarikan pelamar kerja terhadap suatu perusahaan adalah penawaran kompensasi yang diberikan oleh perusahaan kepada karyawan-karyawannya. Luthans (2006) memberikan pandangannya mengenai kompensasi yang memengaruhi ketertarikan para pelamar kerja. Bagi Luthans, kompensasi telah lama dipandang sebagai penghargaan, dan untuk sebagian orang hal itu lebih penting daripada apapun yang diberikan oleh perusahaan. Perusahaan menggunakan kompensasi untuk menarik dan mendorong kinerja karyawan-karyawannya. 
Milkovich dan Newman (2011) mengartikan kompensasi sebagai sesuatu yang didapat karyawan setelah menyelesaikan tugas-tugasnya sesuai dengan hubungan pekerjaan yang telah disepakati kedua belah pihak. Kompensasi adalah segala bentuk pengembalian yang berupa finansial dan pelayanan yang terlihat, serta keuntungan-keuntungan yang didapat karyawan sebagai bagian dari hubungan ketenagakerjaan.

Luthans (2006) dari hasil 72 studinya menemukan bahwa kompensasi merupakan tujuan potensial yang kompleks dan menjadi strategi intervensi penguatan yang positif dan sangat efektif dalam menarik minat pelamar kerja. Hal itu juga ditegaskan dalam Portalhr.com (2011) yang menyebutkan bahwa pada tahun 2011, kompensasi adalah penyebab utama ketidakpuasan karyawan di Amerika Serikat, dipilih oleh $47 \%$ responden dalam survei yang diadakan MarketTools Inc.

Selain adanya penawaran kompensasi sebagai hal yang memengaruhi ketertarikan pelamar kerja terhadap sebuah organisasi. Dukungan organisasi (organizational support) juga merupakan sebuah penawaran yang memiliki pengaruh terhadap ketertarikan (attractiveness) pelamar kerja. Eisenberger dan Stinglhamber (2011) menjelaskan dukungan organisasi (organizational support) adalah dukungan perusahaan terhadap aktivitas pekerjaan karyawan dan kesejahteraan karyawan yang ditempat kerja. Perlakuan-perlakuan perusahaan yang diterima oleh karyawan dianggap sebagai stimulus yang diorganisir dan interpretasikan menjadi persepsi atas dukungan organisasi.

Adanya dukungan organisasi (organizational support) yang dirasakan karyawan nantinya akan memiliki dampak positif berkelanjutan yang berhubungan dengan kontribusi karyawan untuk perusahaan. Rhoades, Armeli dan Eisenberger (2001) serta Eisenberger dan Stiglhamber (2011) dalam penelitiannya menunjukkan bahwa penilaian positif dari karyawan kepada organisasi akan memunculkan rasa kewajiban untuk melindungi dan berkontribusi untuk kesejahteraan perusahaan. Hal ini termasuk rasa memiliki atas perusahaan, meningkatnya keterlibatan dalam aktifitas organisasi, keinginan untuk mencapai tujuan bersama organisasi dan keinginan untuk tetap bertahan dalam organisasi.

Berdasarkan penjelasan di atas dapat ditarik kesimpulan bahwa banyak dari pelamar kerja pada saat ini tidak mendapatkan kenyamanan dan kepuasan di perusahaan setelah mereka bekerja. Salah satu hal yang paling berpengaruh pada keadaan yang mereka alami saat ini adalah keputusan mereka di awal di mana mayoritas pelamar kerja saat mencari pekerjaan hanya berorientasi pada besarnya gaji. Prabowo (2014) menyatakan 
bahwa keterbatasan informasi dan tidak adanya akses untuk mengetahui karakteristik yang ada di perusahaan telah mengakibatkan sebagian besar karyawan merasa tidak ada kecocokan setelah mereka berkerja diperusahaan tersebut. Hal umum yang dirasakan karyawan adalah ketidaknyamanan saat bekerja yang berakibat pada penurunan performa dan kinerja karyawan hingga dampak paling buruk adalah banyaknya karyawan yang akhirnya memutuskan untuk keluar dari perusahaan akibat tidak tahan dengan karakteristik perusahaan mereka.

Proses pencocokan antara pelamar kerja dan karakteristik perusahaan terjadi ketika pelamar kerja dapat mengetahui informasi pekerjaan, baik yang tampak seperti fasilitas perusahaan, gaji dasar dan brand perusahaan di mata sosial, ataupun yang tidak tampak dan bersifat intern seperti kebijakan-kebijakan perusahaan pada situasi tertentu dan lingkungan organisasi. Hasil studi Roberson, Collins, dan Oreg (2005) menunjukkan bahwa informasi spesifik mengenai karakteristik pekerjaan yang ada pada sebuah company profile atau iklan yang dipasang oleh sebuah perusahaan akan memengaruhi ketertarikan pelamar, yang akhirnya juga akan berdampak pada pengambilan keputusan pelamar pekerjaan.

Berdasarkan penelitian yang telah dilakukan sebelumnya, peneliti tertarik untuk melakukan penelitian ini dikarena- kan beberapa alasan. Pertama, masih sangat sedikit literatur di Indonesia yang meneliti mengenai ketertarikan (attractiveness) terhadap organisasi. Kedua, dari segi urgensitas penelitian,pada penelitian - penelitian yang ada sebelumnya peneliti lebih terfokus pada budaya organisasi sehingga tidak terdeskripsi secara rinci budaya organisasi seperti apakah yang memunculkan ketertarikan (attractiveness) bagi pelamar kerja, dengan menggunakan aspek kompensasi (compensation) dan dukungan organisasi (organizational support) yang digunakan dalam penelitian ini, bisa diketahui secara jelas karakter perusahaan seperti apakah yang lebih diminati oleh pelamar kerja saat ini, apakah hanya sebatas kompensasi saja, ataukah lebih pada nilai dan maknamakna dalam bekerja yang diasosiasikan lewat dukungan organisasi.

Dari penjelasan di atas peneliti mengajukan hipotesis bahwa ada pengaruh ketertarikan (attractiveness) terhadap pelamar kerja pada saat diberikan perlakuan berupa pemberian booklet company profile berbasis kompensasi (compensation) dan pemberian booklet company profile berbasis dukungan organisasi (organizational support), di mana booklet berbasis dukungan organisasi (organizational support) lebih meningkatkan ketertarikan (attractiveness) pelamar kerja dibandingkan dengan booklet company 
profile berbasis kompensasi (compensation)".

\section{METODE PENELITIAN}

\section{Desain Penelitian}

Desain penelitian yang digunakan dalam penelitian ini adalah post test only design (Myers \& Hansen, 2002). Desain ini melibatkan dua kelompok partisipan yang diberi perlakuan berbeda pada tiap kelompok, di mana kemudian akan diberikan post test berupa skala ketertarikan (attractiveness) setelah diberikannya perlakuan berupa pemberian informasi booklet company profile berbasis kompensasi, dan booklet company profile berbasis dukungan organisasi.

Tabel 1. Desain Penelitian

\begin{tabular}{ccc}
\hline Eksperimen & Kelompok & Pasca tes \\
\hline Ex.1 & $\mathrm{K} .1$ & $\mathrm{Kt}$ \\
Ex.2 & $\mathrm{K} .2$ & $\mathrm{Kt}$ \\
\hline
\end{tabular}

Keterangan :

Ex.1 : Pemberian Booklet berbasis kompensasi (compensation)

Ex.2 : Pemberian Booklet berbasis dukungan organisasi (organizational support)

K.1 : Kelompok eksperimen 1

K.2 : Kelompok eksperimen 2

Kt : Skala Ketertarikan (attractiveness)

\section{Subjek Penelitian}

Subjek penelitian ini adalah mahasiswa tingkat akhir dengan kriteria (1) minimal telah menempuh semester tujuh. (2) memiliki tujuan untuk bekerja di perusahaan setelah selesai kuliah, (3) subjek belum menikah dan berkeluarga, (4) berasal dari keluarga sosial ekonomi menengah.

\section{Metode Pengumpulan data}

Metode pengumpulan data primer yang digunakan dalam penelitian ini adalah menggunakan alat ukur berupa skala ketertarikan (attractiveness). Skala yang disajikan dalam bentuk post-test. Alat ukur dirancang sendiri oleh peneliti berdasarkan aspek-aspek pada variabel ketertarikan (attractiveness) menurut Lievens, Decaesteker, Coetsier, dan Geirnet (2001) serta Highhouse, Lievens dan Sinar (2003). Terdapat tiga komponen ketertarikan di antaranya adalah persepsi ketertarikan (attractiveness perception), intention (keinginan), dan prestise (prestige). Pernyataan yang digunakan dalam skala adalah penyataan mendukung (favorable) dan pernyataan yang tidak mendukung (unfavorable). Pernyataan pada skala memiliki lima alternatif 
jawaban, yaitu: Sangat sesuai (SS), Sesuai (S), Netral (N), Tidak Sesuai (TS), Sangat Tidak Sesuai (STS). Hasil uji reliablitas menunjukkan bahwa skala ketertarikan memiliki koefisien korelasi 0.936 .

\section{Prosedur Intervensi}

Prosedur eksperimen ini terbagi ke dalam, (1) Persiapan penelitian, yang meliputi persiapan dan penyusunan alat ukur berupa skala ketertarikan (attractiveness), (2) Menyiapkan materi perlakuan berupa dua desain booklet company profile berbasis kompensasi (compensation) dan dukungan organisasi (organizational support) (3) Pelaksanaan eksperimen (4) Pengukuran skala ketertarikan (attractiveness).

Secara keseluruhan, eksperimen diawali dengan pengenalan mengenai jalannya eksperimen dan prosedur yang dijalankan. Setelah itu, subjek diacak untuk menentukan booklet manakah yang akan mereka dapatkan. Setelah subjek menerima booklet berdasarkan acak tadi, selanjutnya subjek masuk ke dalam ruang eksperimen yang telah dikondisikan untuk diberikan kesempatan membaca dan mencermati booklet company profile yang mereka dapatkan selama 10 menit. Lalu setelah membaca booklet tersebut peserta diminta untuk mengisi post test berupa skala ketertarikan (attractiveness).

\section{Teknik Analisis Data}

Dalam penelitian ini metode analisis yang digunakan adalah Mann Whitney $U$ Test. Kaidah yang digunakan dalam uji hipotensis adalah hipotesis diterima jika $p<0.05$. Proses analisis data dalam penelitian menggunakan software Statistical Package Sosial Science (SPSS) versi 16.0 for windows.

\section{HASIL PENELITIAN}

\section{Deskripsi Data Penelitian}

Deskripsi statistik dari nilai hipotetik dan empirik variabel ketertarikan (attractiveness) dapat dilihat pada tabel dan grafik berikut: 


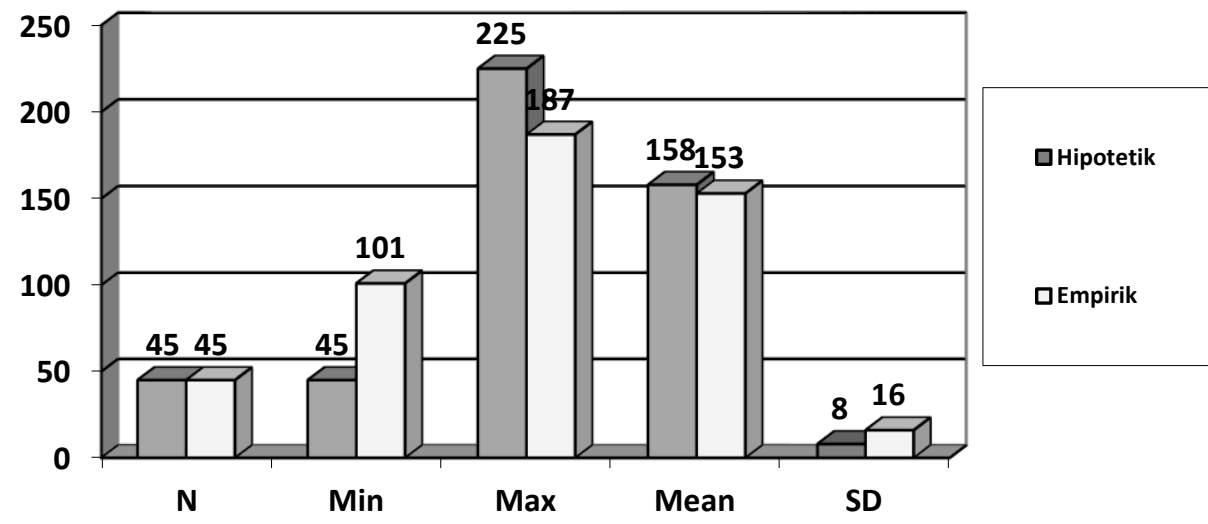

Gambar 1. Grafik Deskriptif Statistik

Penelitian ini mengkategorisasikan pada skala ketertarikan (attrac-tiveness) subjek berdasarkan standar 5 kelompok, disusun berdasarkan nilai empirik yang yaitu sangat rendah, rendah, sedang, ting- dapat dilihat melalui tabel dan grafik gi dan sangat tinggi. Kategorisasi subjek berikut:

Tabel 2. Kategorisasi Skor Ketertarikan (attractiveness)

\begin{tabular}{|c|c|c|c|}
\hline Kategorisasi & Skor & Jumlah & Persentase \\
\hline Sangat Tinggi & $178<X$ & 3 & $5 \%$ \\
\hline Tinggi & $161<X \leq 178$ & 18 & $30 \%$ \\
\hline Sedang & $145<X \leq 161$ & 21 & $35 \%$ \\
\hline Rendah & $129<X \leq 145$ & 13 & $21,67 \%$ \\
\hline Sangat Rendah & $X<129$ & 5 & $8,33 \%$ \\
\hline \multicolumn{2}{|c|}{ Total } & 60 & $100 \%$ \\
\hline
\end{tabular}

\section{Hasil Uji Asumsi}

Rangkuman Uji normalitas dapat dilihat pada tabel di bawah ini:

Tabel 3. Hasil Uji Normalitas Data Penelitian

\begin{tabular}{cccc}
\hline Variabel & $\begin{array}{c}\text { Indeks Kolmogorov } \\
\text { Smirnov (K-SZ) }\end{array}$ & $\begin{array}{c}\text { Kaidah Signifikansi } \\
\text { Normalitas }\end{array}$ & Keterangan \\
\hline Ketertarikan & 0,200 & $\mathrm{P}>0,05$ & Normal \\
\hline
\end{tabular}

Keterangan Tabel: (p) adalah indeks normalitas kolmogorov smirnov 
Kaidah yang digunakan dalam uji normalitas adalah data dikatakan normal jika $\mathrm{p}>0,05$. Berdasarkan data yang diperoleh, disimpulkan bahwa data pada penelitian ini taraf signifikansi 0,200 pada dua kelompok. Hal tersebut menegaskan bahwa data penelitian ini normal. Selain normalitas, perlu dianalisis homogenitasnya. Hasilnya adalah sebagai berikut:

Tabel 4. Uji Homogenitas Data Penelitian

\begin{tabular}{cccc}
\hline Variabel & Taraf Signifikansi & $\begin{array}{c}\text { Kaidah Signifikansi } \\
\text { Homogenitas }\end{array}$ & Keterangan \\
\hline Ketertarikan & 0,024 & $\mathrm{P}>0,05$ & Tidak Homogen \\
\hline
\end{tabular}

Kaidah yang digunakan dalam uji homogentitas adalah data homogen jika taraf signifikansi $>0,05$, sedangkan pada penelitian ini taraf signifikansi 0,024 . Hal ini menunjukkan bahwa data tidak homogen. Oleh karena itu analisis data menggunakan Analisis parametrik independent sample $T$ Test tidak dapat dilakukan

karena tidak memenuhi kaidah uji asumsi (Uji normalitas dan Uji Homogenitas). Dengan demikian, analisis data yang digunakan pada penelitian ini adalah analisis non parametrik dengan teknik Mann-Whiney U Test.

\section{Hasil Uji Hipotesis}

Tabel 5. Pengaruh Booklet Company profile Berbasis Kompensasi (compensation) dan Dukungan Organisasi

\begin{tabular}{ccc}
\hline & Variabel & Keterangan \\
\cline { 2 - 3 } Asymp. Sig. (2-tailed) & Ketertarikan & Signifikan \\
$\boldsymbol{P}<0,05$ & 0,021 & \\
\hline
\end{tabular}

\footnotetext{
Keterangan Tabel:

$P \quad$ : Taraf Signifikansi

Variabel : Variabel tergantung
}

Hasil analisis data statistik dalam penelitian ini menunjukkan adanya pengaruh yang signifikan. Kaidah dalam penelitian menyatakan bahwa hipotesis diterima jika taraf signifikansi $<0,05$, sedangkan pada penelitian ini menun- jukkan bahwa taraf signifikansi sebesar 0,021, hal ini menegaskan bahwa hipotesis penelitian ini diterima, di mana ada pengaruh ketertarikan (attractiveness) terhadap pelamar kerja saat diberikan perlakuan berupa pemberian booklet 
company profile berbasis kompensasi (compensation) dan dukungan organisasi (organizational support).

Tabel 6. Tabel Persentase ketertarikan antara booklet company profile berbasis kompensasi dan dukungan organisasi

\begin{tabular}{ccc}
\hline Subjek & $\boldsymbol{N}$ & Mean Rank \\
\hline Booklet Kompensasi & 30 & 35,70 \\
Booklet Dukungan Organisasi & 30 & 25,30 \\
\hline
\end{tabular}

Keterangan Tabel :

$\begin{array}{ll}N & \text { : Jumlah Subjek Penelitian } \\ \text { Mean Rank } & \text { : Persentase Ketertarikan }\end{array}$

Tabel 6 di atas menunjukkan bahwa dukungan organisasi (organizational support) memiliki nilai mean rank lebih besar, yaitu 35,70, sedangkan booklet company profile kompensasi (compensation) hanya sebesar 25,30. Hal ini sekaligus menegaskan bahwa booklet company profile berbasis dukungan organisasi lebih meningkatkan ketertarikan pelamar kerja daripada booklet company profile berbasis kompensasi.

\section{PEMBAHASAN}

Berdasarkan penelitian yang dilakukan pada ketertarikan pelamar kerja terhadap booklet company profile, maka didapatkan hasil sebagai berikut: 35\% pelamar kerja memiliki ketertarikan sedang, kemudian 30\% tergolong memiliki ketertarikan tinggi, dan 21,6\% tergolong memiliki ketertarikan rendah. Sedangkan selebihnya, yaitu 8,33 \% subjek tergolong memiliki ketertarikan sangat rendah dan hanya $5 \%$ subjek yang memiliki ketertarikan sangat tinggi. Adapun untuk lebih jelasnya skor ketertarikan dapat di lihat pada grafik di bawah ini: 


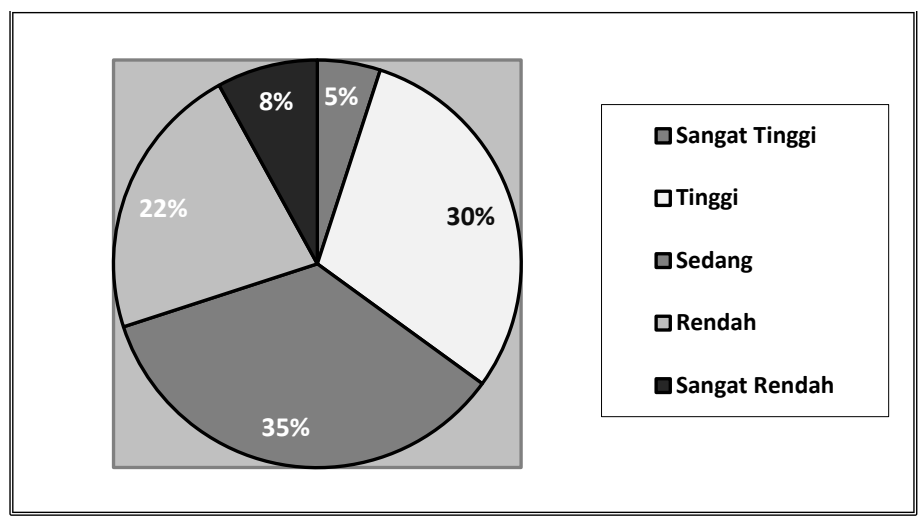

Gambar 2. Grafik Skor Ketertarikan (Attractiveness)

Mengacu pada data di atas, dapat diketahui bahwa tinggi atau rendah persentase ketertarikan pelamar kerja terhadap perusahaan, dipengaruhi oleh adanya kecocokan dengan karakteristik perusahaan yang diwujudkan dalam informasi spesifik mengenai kebijakan-kebijakan pada perusahaan tersebut. Hal itu dikarenakan pada saat proses membaca booklet company profile tersebut pelamar kerja mendapatkan informasi spesifik mengenai perusahaan, sehingga pelamar kerja dapat memahami karakter perusahaan lebih mendalam, dan dari informasi tersebut dapat membantu pelamar kerja memutuskan apakah karakter perusahaan tersebut cocok dengan dirinya atau tidak.

Adapun untuk mengetahui booklet mana yang lebih meningkatkan ketertarikan (attractiveness) pelamar kerja dapat diketahui melalui skor mean rank, dan bedasarkan analisis data diketahui bahwa skor mean rank booklet dukungan organi- sasi memperoleh nilai 35,70, sedangkan untuk booklet kompensasi memperoleh nilai 25,30. Hal ini juga semakin menguatkan hipotesis penelitian di mana booklet company profile berbasis dukungan organisasi (organizational support) lebih meningkatkan ketertarikan (attractiveness) pelamar kerja dibandingkan dengan booklet company profile berbasis kompensasi (compensation).

Dalam konteksnya sebagai strategi, kompensasi merupakan salah satu strategi yang umum digunakan oleh banyak perusahaan untuk menarik pelamar kerja bekerja di perusahaannya. Cara ini dinilai cukup efektif dalam hal menarik perhatian pelamar kerja pada perusahaan, namun hal itu bukanlah cara yang efektif dalam mempertahankan karyawan. Bagi karyawan yang hanya berorientasi pada kompensasi, karyawan tersebut hanya akan bekerja untuk uang, di mana hal ini akan berdampak pada loyalitas karyawan 
yang tidak akan terbangun, serta kebutuhan sosioemosional karyawan di perusahaan tersebut juga tidak terpenuhi. Dalam hal ini berarti pada dasarnya karyawan bekerja tidak semata-mata hanya demi uang, namun lebih mengutamakan kualitas suasana dan terpenuhinya kebutuhan sosioemosional, serta kehidupan bekerja yang lebih bermakna.

Adanya dukungan organisasi (organizational support) pada karyawan mengacu pada tingkat kepercayaan karyawan terhadap perusahaan dan pekerjaan yang diberikan kepada karyawan, serta bagaimana perusahaan menghargai kontribusi dan peduli terhadap kesejahteraan karyawan di tempat kerja (Shanock, Miller, \& Baran, 2012). Dukungan organisasi dari perusahaan terhadap karyawan merupakan sebuah keuntungan timbal balik yang dapat dirasakan oleh kedua belah pihak, baik karyawan itu sendiri maupun perusahaan. Bagi karyawan dengan adanya dukungan organisasi hal tersebut akan memompa semangat karyawan untuk bekerja sebaik mungkin, melaksanakan tanggung jawab, dan berkontribusi maksimal untuk perusahaan dimana pada akhirnya akan berimbas pada kemajuan perusahaan.

Adapun dukungan organisasi di sini juga berupaya untuk menekan perilaku job hopping, di mana perilaku job hopping adalah hal yang paling dihindari oleh perusahaan manapun karena menye- babkan kerugian besar bagi perusahaan. Kompas.com (2016) menyebutkan bahwa perusahaan yang kehilangan karyawan harus melakukan rekruitmen ulang untuk mengganti posisi jabatan yang ditinggalkan tersebut, terlebih jika karyawan tersebut merupakan karyawan yang memiliki peran penting bagi perusahaan, hal tersebut akan mengakibatkan kekosongan peran pada struktur organisasi. Dalam segi finansial, perusahaan juga harus mengeluarkan biaya yang besar untuk proses rekutmen, hal itu belum termasuk biaya pelatihan pengembangan diri karyawan.

Dari alasan-alasan tersebutlah dukungan organisasi (organizational support) muncul sebagai solusi segar bagi perusahaan untuk mengatasi perilakuperilaku job hopping pada karyawan. Pengalaman yang muncul akibat adanya dukungan organisasi yang dirasakan oleh karyawan akan memberikan nilai positif terhadap karyawan, di mana pada akhirnya akan memunculkan rasa memiliki dan tanggung jawab terhadap perusahaan. Lebih lanjut, dukungan organisasi yang dirasakan oleh karyawan juga akan meningkatkan kinerja karyawan dan loyalitas karyawan sehingga karyawan akan berkontribusi penuh bagi perusahaan. 


\section{SIMPULAN DAN SARAN}

\section{Simpulan}

Berdasarkan hasil yang diperoleh dari pengolahan data serta pembahasan di atas, penulis dapat menarik beberapa kesimpulan. Adapun hal-hal yang dapat disimpulkan dari penelitian ini adalah sebagai berikut. Pertama: Hasil analisis data statistik dalam penelitian ini menunjukkan adanya pengaruh yang signifikan. Kaidah dalam penelitian menyatakan bahwa hipotesis diterima jika taraf signifikansi $<0,05$, sedangkan pada penelitian ini menunjukkan bahwa taraf signifikansi sebesar 0,021, hal ini menegaskan bahwa hipotesis penelitian ini diterima.

Kedua: Booklet company profile berbasis dukungan organisasi (organizational support) memiliki nilai mean rank lebih besar, yaitu 35,70, sedangkan booklet company profile berbasis kompensasi (compensation) hanya sebesar 25,30. Hal ini sekaligus menegaskan bahwa booklet company profile berbasis dukungan organisasi lebih meningkatkan ketertarikan pelamar kerja daripada booklet company profile berbasis kompensasi.

Ketiga: Hasil pengolahan data deskriptif menunjukkan bahwa 35\% pelamar kerja memiliki ketertarikan sedang, kemudian 30\% tergolong memiliki ketertarikan tinggi, dan 21,6\% tergolong memiliki ketertarikan rendah. Sedangkan selebihnya, yaitu 8,33\% subjek tergolong memiliki ketertarikan sangat rendah dan 5\% subjek memiliki ketertarikan sangat tinggi.

\section{Saran}

Selanjutnya, dari hasil penelitian ini, dapat disarankan beberapa hal. Pertama: Untuk Pelamar Kerja. Ketersediaan informasi mengenai perusahaan merupakan hal yang sangat penting supaya pelamar kerja dapat memahami dan mempelajari perusahaan yang akan mereka tuju. Untuk itu informasi yang spesifik mengenai perusahaan adalah poin utama dalam media informasi yang akan disosialisasikan ke pelamar kerja. Semakin lengkap informasi yang dapat pelamar gali mengenai perusahaan tersebut, maka semakin mudah pula proses pencocokan antara karakteristik perusahaan dengan karakteristik pribadi pelamar kerja.

Kedua: Untuk perusahaan. Pemberian informasi dalam bentuk booklet memberikan informasi yang lebih rinci daripada media cetak lainnya seperti brosur atau leaflet, namun di era digital seperti saat ini media internet seperti website juga merupakan media yang tepat sebagai wadah untuk menyampaikan informasi secara efisien.

Ketiga: Untuk Peneliti selanjutnya. Kontrol subjek harus lebih diperhatikan 
lagi, dalam penelitian ini kriteria utama hanya subjek yang ingin bekerja ke perusahaan, akan lebih baik jika ditambahkan bidang perusahaan seperti apa dimaksud, kemudian disesuaikan dengan subjek yang tertarik dengan bidang perusahaan yang dipilih.

\section{DAFTAR PUSTAKA}

Anthony, R.N. \& Govindarajan, V. (2007). Sistem pengendalian manajemen. Jakarta: Salemba Empat

Careernews. (2014). Kutu loncat tak banyak diminati perusahan. Diunduh dari: http://careernews. id/issues/view/2187-Kutu-LoncatTak-Banyak-Diminati-Perusahaan/ Tanggal 20 Februari 2016

Eisenberger, R., \& Stinglhamber, F. (2011). Perceived organizational support. Washington DC: American Psychological Asosiation

Highhouse, S., Lievens, F., \& Sinar, E. (2003). Measuring attraction to organizations. Journal of Educational and Psychological Measurement, 63 (6), 986-1001

Kompas.com. (2016). Pilih karyawan setia atau kutu loncat. Diunduh dari: http://www.kompas.com/tips/karir/ pilih-karyawan-setia-atau-kutuloncat-445 / Tanggal 20 Februari 2016
Lievens, F.., Decaesteker, C., Coetsier, P., \& Geirnet, J. (2001). Organizational attractiveness for perspective applicants: a person-organization fit perpective. Journal Applied Psychology 50 (1) 30-51

Luthans, F. (2006). Organizational behavior $10^{\text {th }}$ Edition. Yogyakarta; ANDI

Milkovich, G., Newman, J., \& Gerhart, B. (2011). Compensation. New York: Mc Graw hill

Myers, A., \& Hansen, C. (2002). Experimental psychology. USA: Wadsworth

PortalHR.com. (2011). Gaji penyebab utama ketidakpuasan karyawan. Diunduh dari: http://portalhr.com /berita/gaji-penyebab-utamaketidakpuasan-karyawan/ Tanggal 5 Oktober 2015

Prabowo. (2014). Dampak buruk tingkat turnover karyawan yang tinggi. Diunduh dari: http://www.bestlife. co.id/lifestyle/the.good.life/dampak .buruk.tingkat.turnover.karyawan.y ang.tinggi/004/001/251, tanggal: pada 10 Juni 2015

Roades, L., Eisenberger, R., \& Armenli, S. (2001). Affective commitment to the organization: the contribution of perceived organizational support. Journal of Applied Psychology, 86, 825-836 
Roberson, Q.M., Collins, C.J., \& Oreg, S. (2005). The effects of recruitment message specificity on applicant attraction to organizations. Journal of Business and Psychology, 19 (3), 319-339

Shanock, L.R., Baran, B.E., \& Miller, L.R. (2012). Advancing organizational support theory into twenty-first century world of work. Journal Bus psycol (27), 123-147

Turban, D. (2001). Organizational attractiveness as an employer on college campus: an examination of the applicant Population. Journal of vocational behavior 58, 203-312 


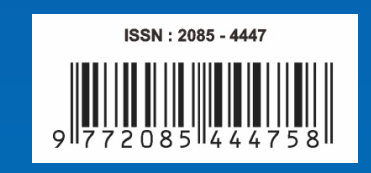

